\title{
Cross-cultural adaptation and validation of the VISA-A questionnaire for Chilean Spanish-speaking patients
}

\author{
Andres Keller ${ }^{1}$, Pablo Wagner ${ }^{1,2}$, Guillermo Izquierdo ${ }^{1}$, Jorge Cabrolier ${ }^{1}$, Nathaly Caicedo ${ }^{1}$, Emilio Wagner ${ }^{1 *}$ \\ and Nicola Maffulli ${ }^{3}$
}

\begin{abstract}
Background: The purpose of this study is to translate, culturally adapt, and validate the VISA-A questionnaire for Chilean Spanish speakers with Achilles tendinopathy (AT), which has been originally developed for English-speaking population.

Methods: According to the guidelines published by Beaton et al., the questionnaire was translated and culturally adapted to Chilean patients in six steps: initial translation, synthesis of the translation, back translation, expert committee review, test of the pre-final version (cohort $n=35$ ), and development of VISA-A-CH. The resulting Chilean version was tested for validity on 60 patients: 20 healthy individuals (group 1), 20 patients with a recently diagnosed AT (group 2), and 20 with a severe AT that already initiated conservative treatment with no clinical improvement (group 3). The questionnaire was completed three times by each participant: at the time of study enrollment, after an hour, and after a week of the initial test.

Results: All six steps were successfully completed for the translation and cultural adaptation of the VISA-A-CH. VISA-A-CH final mean scores in the healthy group was significantly higher than those in the other groups. Group 3 had the lowest scores. Validity showed excellent test-retest reliability (rho $c=0.999$; Pearson's $r=1.000$ ) within an hour and within a week (rho $c=0.837$; Pearson's $r=0.840$ ).

Conclusions: VISA-A was translated and validated to Chilean Spanish speakers successfully, being comparable to the original version. We believe that VISA-A-CH can be recommended as an important tool for clinical and research settings in Chilean and probably Latin-American Spanish speakers.
\end{abstract}

Keywords: VISA-A, Achilles tendinopathy, Score validation, Spanish validation

\section{Background}

Achilles tendinopathy (AT) is the most common cause of posterior heel pain [1-3] in athletes and non-athletes [4]. The activities most related to this pathology are those involving jumping and running $[4,5]$. The incidence of AT has been increasing in the last decades, with a prevalence of $10 \%$ in runners $[4,6]$. In terms of its clinical presentation, pain in the middle portion of the Achilles tendon during and after physical activity, increased volume in the involved region of the tendon,

\footnotetext{
*Correspondence: ewagner@alemana.cl; emiliowagner@gmail.com ${ }^{1}$ Department of Orthopedics, Universidad del desarrollo - Clinica Alemana de Santiago, Vitacura 5951, 7650568 Santiago, Chile

Full list of author information is available at the end of the article
}

and morning stiffness are frequent. The above symptoms usually decrease when the patient reduces the load or the level of activity but tend to recur when the activity is resumed $[7,8]$. For these reasons, AT is a frequent cause of limitation in the physical activity of patients, with the consequent negative impact on their general health.

Despite the high incidence and its multi-factorial etiology [9], the decision to undertake conservative or operative treatment in patients with AT is still under debate [10], though surgical treatment is generally recommended only following failure of conservative measures [11, 12]. Regardless of the management path chosen, the aim of treatment is to return the patient to clinical and functional wellbeing. The achievement of these objectives can be difficult to compare

(C) The Author(s). 2018 Open Access This article is distributed under the terms of the Creative Commons Attribution 4.0 International License (http://creativecommons.org/licenses/by/4.0/), which permits unrestricted use, distribution, and 


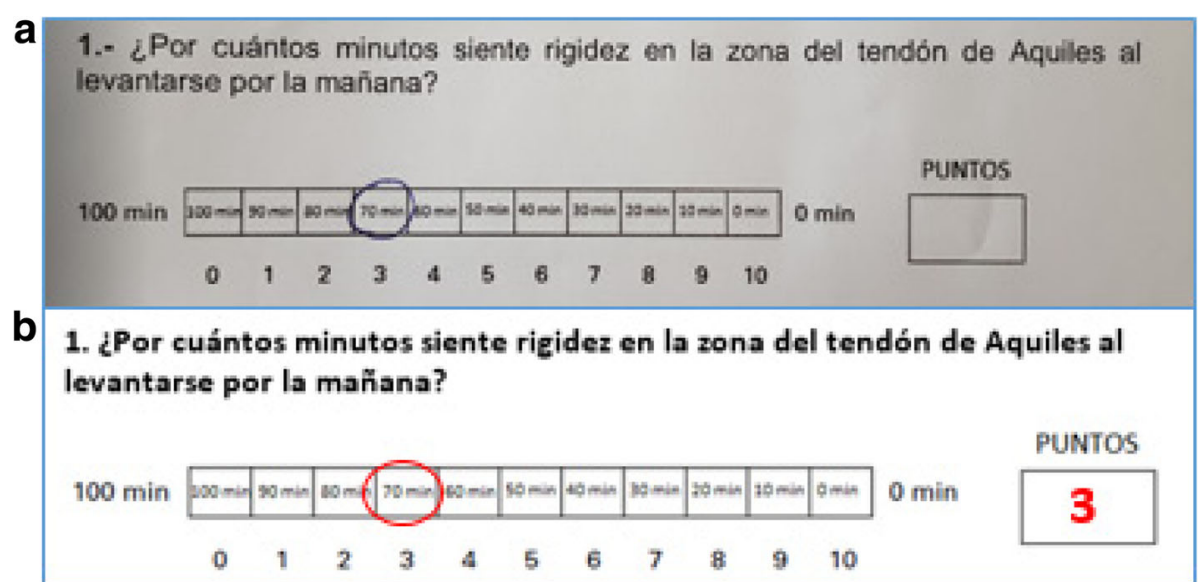

Fig. 1 Example of incorrectly answered question during the test adaptation. a The participant did not fill the "PUNTOS" (score) box. b Correct way of answering

objectively between different studies, mainly because of the ways in which they are measured, and possible difference in severity and clinical presentation of the condition.

A simple, self-administered questionnaire was developed by the Victorian Institute of Sports Assessment to be completed by patients with AT, called VISA-A (Victorian Institute of Sport Assessment-Achilles Questionnaire), which assesses several aspects such as: pain (questions 1-3), function (questions 4-6), and activity (questions 7 and 8). For this reason, it can be used to determine the clinical severity of the condition and provide a guide for treatment, as well as to monitor the effects of treatment, constituting a validated, reliable, and accurate tool to specifically evaluate patients with AT [13]. Moreover, it is useful to compare results between different studies [14-17]. The questionnaire was developed for English-speaking populations: this is the reason why it is necessary to translate, culturally adapt, and validate [18] the VISA-A in other languages. This has already been the case for the Swedish- [14], Italian- [16], and German-speaking populations [19].

The purpose of this study was to translate, culturally adapt, and validate the VISA-A questionnaire for the Spanish-speaking Chilean population with AT.

\section{Methods}

According to the guidelines published by Beaton et al. [18], the questionnaire was translated and culturally adapted to Spanish-speaking Chilean patients in six steps.

Table 1 VISA-A-CH scores of patients with AT (group 2) at different time points

\begin{tabular}{llllll}
\hline Answer time (hours) & $N$ & Min & p50 & Max & Mean \\
\hline 0 & 20 & 28 & 71 & 100 & 67.16 \\
1 & 20 & 29 & 70.5 & 100 & 67.33 \\
168 & 20 & 28 & 69.5 & 100 & 65.27 \\
\hline
\end{tabular}

Step 1. Initial translation: two bilingual translators whose mother tongue was Spanish developed two independent translations. One of the translators had medical knowledge of the concepts and terms (an orthopedic surgeon with specialization in foot and ankle); the other translator had no medical knowledge or relation with health care system (native translator).

Step 2. Synthesis of translation: both translators agreed on their translations and developed a common translation (preliminary translation V1.0).

Step 3. Retrograde translation: with the preliminary version V1.0 in hand and blind to the original version (VISA-A), two non-medically expert translators whose mother tongue was English translated the questionnaire back into English.

Step 4. Expert committee: a committee was organized with the participation of the original translators, other expert translators, orthopedic surgeons with experience in foot and ankle surgery, and other health care professionals, to review all translations and to develop the pre-final version of the questionnaire (V2.0).

Step 5. Test of the V2.0 questionnaire: this stage ensured that the adapted version was equivalent to the original version. The questionnaire was completed by a cohort of 35 people. Later, they were interviewed to discuss errors, what they understood of each question, and the difficulty to answer them.

Table 2 VISA-A-CH scores of patients with AT and failure to conservative treatment (group 3)

\begin{tabular}{llllll}
\hline Answer time (hours) & $N$ & Min & p50 & Max & Mean \\
\hline 0 & 20 & 14 & 22.5 & 40 & 24.7 \\
1 & 20 & 14 & 22.5 & 40 & 24.7 \\
168 & 20 & 14 & 23.5 & 35 & 26 \\
\hline
\end{tabular}


Step 6. Development of the final version (VISA-A-CH): after analyzing the opinions, doubts, and suggestions of the interviewees, corrections were made to V2.0 in each one of its items, with the final version being developed V3.0 (VISA-A-CH) (Additional file 1).

After the translation and cultural adaptation, the VISA-A-CH questionnaire was subjected to validation.

After approval by the local ethics committee, the VISA-A-CH was prospectively delivered to 60 patients divided into three groups: group 1, 20 healthy patients with no AT symptoms and signs (control group); group 2, 20 patients with a recently diagnosed AT; and group 3, 20 patients with severe AT who already initiated conservative management with no clinical improvement. These patients were all older than 18, and all had been selected and evaluated by a trained foot and ankle orthopedic surgeon in a single center in Santiago, Chile. Informed consent was obtained from all individual participants included in the study.

The questionnaire was completed anonymously three times by each participant: at the time of study enrollment (time 0$)$, after $1 \mathrm{~h}($ time +1$)$, and after 1 week of the initial test (time +7 ).

Descriptive statistics were calculated, using percentile, mean, and standard deviation. The questionnaires (three each participant, 180 in total) were evaluated using mixed models to control intra- and inter-patient variability. We used significance level of 95\%, and the data were processed with software STATA version 14.0.

\section{Results}

To develop the translation and cultural adaptation of the questionnaire (step 5 from the "Methods" section), initially, a cohort of 23 men and 12 women with age of 18 to 50 years were interviewed to check for score structure and reading comprehension. Half of them were fourth year medical students from a Chilean University. The other half were firefighters from the regional fire station. Each participant was given a copy of VISA-A-CH V2.0 to read and respond as directed. At the end of the survey, feedback on the questionnaire was requested.

Twenty-seven participants (77\%) did not answer the questionnaire in a structural correct form (i.e., ticking the relevant box) as shown in Fig. 1 .

Regarding the comprehension of the questions, all the participants reported having no problem understanding what was being asked.

On the other hand, 16 participants (45\%) reported that in some of the questions there was no precise alternative for someone healthy and asymptomatic (for example, the maximum score for question no. 7 was: "Yes, I do sport or physical activity to the same or even to a higher level since the discomfort began"). Healthy participants have never experienced any discomfort. However, as expected, they responded correctly with the maximum score for those questions.

For the validation stage of VISA-A-CH, three groups were selected to complete the questionnaire as explained

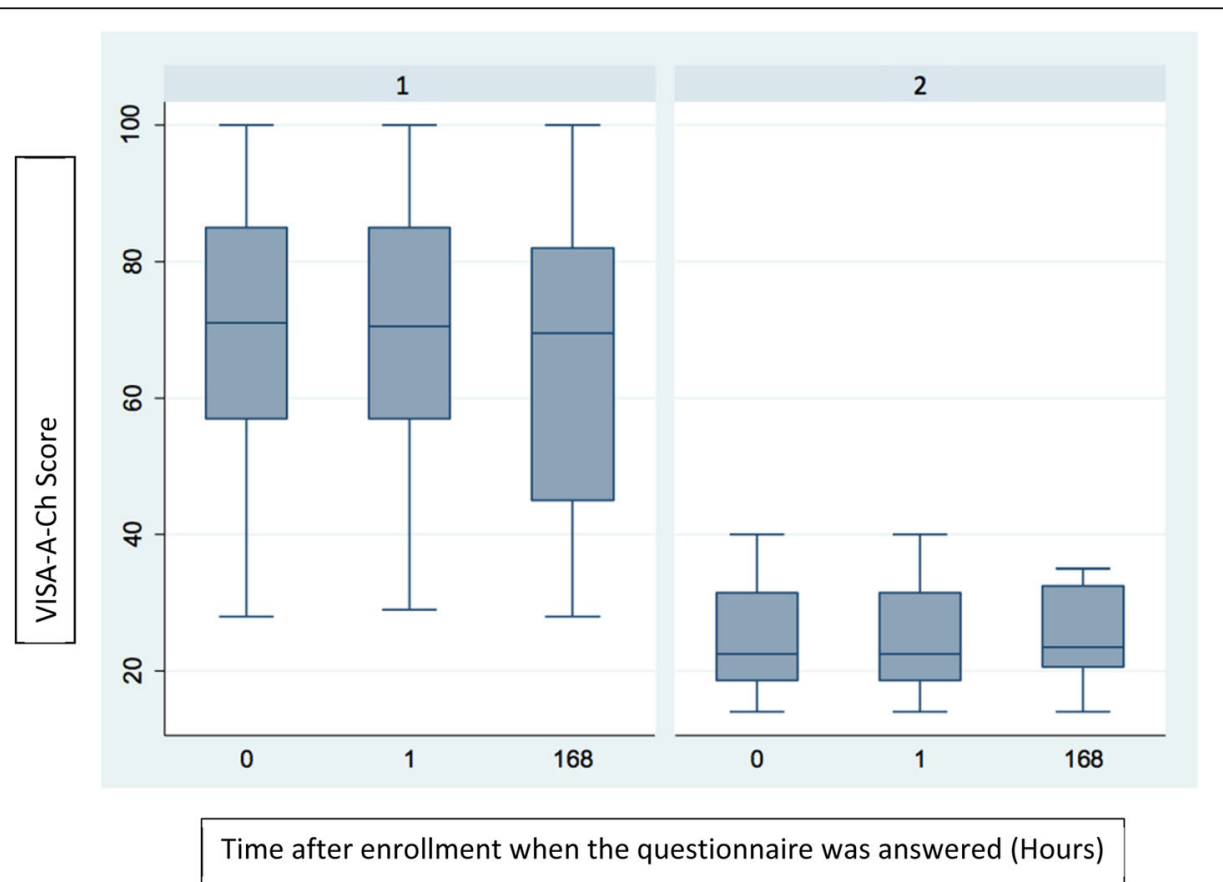

Fig. 2 Figure showing scores (y axis) in groups 2 and 3 throughout time ( $x$ axis, in hours). 0, 1, and 168 h (7 days). Column 1, group 2; column 2, group 3 
in the "Methods" section: group 1: 20 healthy subjects, 10 men and 10 women, with a mean age of 38 years (range 20-55); group 2: 20 patients with a recently diagnosed AT, 13 men and 7 women, with a mean age of 41 years (25-49); and group 3: 20 patients with a severe AT that already initiated conservative treatment with no clinical improvement, 14 men and 6 women, with a mean age of 43 years (29-51).

The control group obtained 100 points in all measurements at all time points (at the time of enrollment, after $1 \mathrm{~h}$, and after a week). Group 3 had the lowest scores of all the groups at all time points (time $0,+1,+7)$. Tables 1 and 2 show the scores of groups 2 and 3 (Tables 1 and 2). When comparing questionnaire results in groups 2 and 3, the $p$ value of 0.335 indicates that there was no significant change in re-test scores at an hour (rho $c=0.999$; Pearson's $r=1000$ ) or at a week from diagnosis (rho $c=0.837$; Pearson's $r=0.840$ ). Figure 2 depicts the scores obtained by the patients in groups 2 and 3 at different time points, showing no change. The final version of the VISA-A-CH questionnaire is shown in Figs. 3, 4, and 5.

\section{Discussion}

With the multinational advance of research, it is necessary when comparing studies to have equivalent scoring systems, questionnaires, and results [20,21]. In the case of self-administered questionnaires, comparing results between studies with different language and culture populations may lead to systematic errors if these assessment tools are not equivalent to the original [22]. Since most questionnaires are developed in English, they have to be validated in other languages. This is not just a translation issue: when the questionnaire is used in another country or with immigrants, it must necessarily be culturally adapted. Beaton et al. developed a clinical guideline for cultural translation and adaptation of self-report scores [18]. It has progressive stages of translation, synthesis,

\section{Visa-A-Ch: Cuestionario de puntaje para tendón de Aquiles del Instituto de Victoria.}

En este cuestionario, el término dolor se refiere específicamente al dolor de la región del tendón de Aquiles.

Conteste en los casilleros de respuesta y luego coloque el puntaje de cada pregunta en la casilla PUNTOS.

1.- ¿Por cuántos minutos siente rigidez en la zona del tendón de Aquiles al levantarse por la mañana?

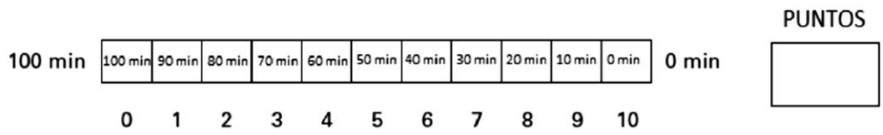

2.- ¿Una vez que ha entrado en calor durante el dia, siente dolor al estirar completamente el tendón de Aquiles cuando apoya la punta de los pies en el borde de un escalón? (manteniendo la rodilla estirada)

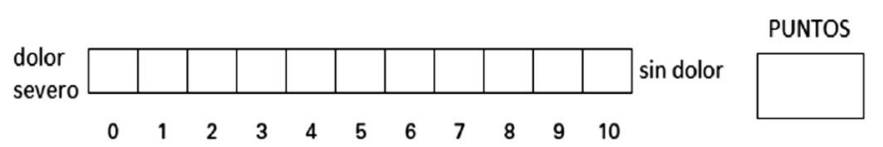

3.- ¿Después de caminar en terreno plano por 30 minutos, presenta dolor durante las siguientes dos horas? (si no es capaz de caminar en terreno plano por 30 minutos debido al dolor, conteste 0 en esta pregunta).

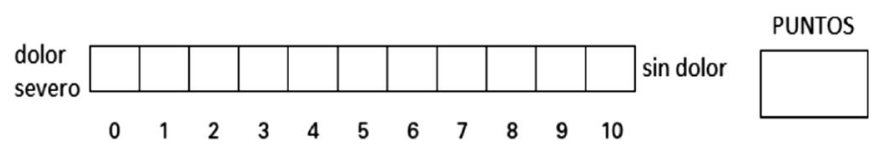

Fig. 3 Image of the final version of the VISA-A-CH questionnaire 


\section{4.- ¿Siente dolor al bajar escaleras a paso normal?}

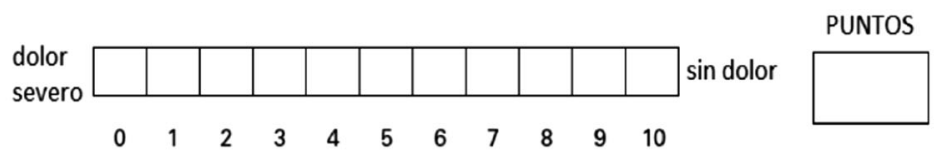

5.- ¿Siente dolor al colocarse en punta de pies en una superficie plana 10 veces seguidas, o inmediatamente después?

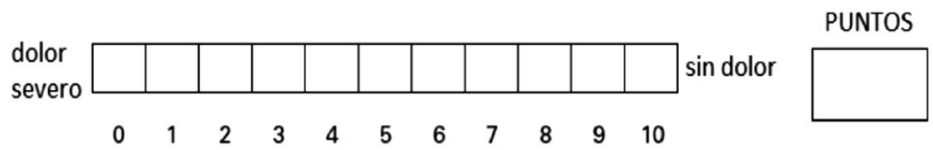

6.- ¿Cuántos saltos en un solo pie puede realizar sin dolor?

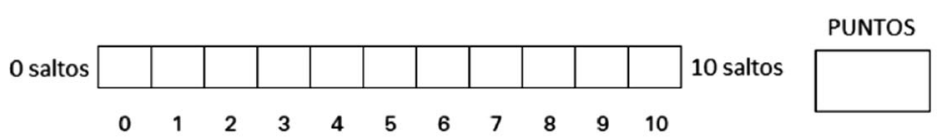

7.- ¿Se encuentra actualmente practicando algún deporte o algún tipo de actividad física? Si no tiene molestias en la zona del tendón de Aquiles marque 10 puntos.

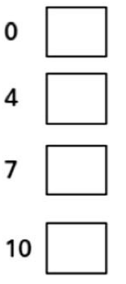

No, ninguno.

Si, pero el deporte o actividad física ha sufrido modificaciones o adaptaciones debido al dolor

Si, realizo deporte o actividad física sin restricciones, pero no en el mismo nivel desde que comenzaron las molestias.

Si, realizo deporte o actividad física al mismo o incluso a un nivel superior desde que comenzaron las molestias.

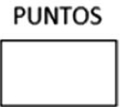

Fig. 4 Image of the final version of the VISA-A-CH questionnaire

reverse translation, expert committee, test of the questionnaire, and development of the final version.

The VISA-A, originally developed in English, is a reliable and reproducible questionnaire to compare results among patients with different degrees of AT severity. We have to remember it is not a diagnostic tool, but a valid way to measure the condition of the Achilles tendon. Its continuous numerical score has the potential to be used in clinical and research settings, but it was not designed to be a diagnostic tool [13]. Although the translation of the VISA-A was not difficult, cultural adaptation in relation to how to complete the questionnaire was the first inconvenience we encountered. Although the score of these evaluations was not affected, it showed how unclear it was in its filling instructions (77\% of respondents did not respond in the boxes requested). For this reason, the VISA-A-CH developers added an instruction phrase on how to fill it: "Answer in the answer boxes and then fill the box labeled PUNTOS (translation for score) with the score for each question." When analyzing test-retest reliability, no significant changes were found between the scores obtained in all patient groups. They all had scores not statistically different at time $0,+1$ and +7 . A week after diagnosis, groups 2 and 3 patients, despite the medical indications and the schedule of eccentric exercises given to the patients, showed no change in score, perhaps highlighting that, despite the correct exercises having been prescribed and implemented, in the short term, the symptoms of AT do not change.

We point out that the use of the VISA-A-CH is likely to transcend the country where it was developed, namely Chile, and be used in all the Spanish-speaking countries in Latin America. We are aware of the linguistic differences which have developed during centuries between the Spanish language spoken in Spain and that of Latin America. In this respect, we suspect that a separate cross-cultural adaptation will be needed for Spain. 
8.- Por favor, responda sólo una pregunta ya sea $8 \mathrm{~A}, 8 \mathrm{~B} \circ 8 \mathrm{C}$, según corresponda:

Si usted no tiene dolor al realizar deportes que exigen al tendón de Aquiles, por favor responda sólo la pregunta $\mathbf{8 A}$.

Si usted tiene dolor al realizar deportes que exigen al tendón de Aquiles, pero éste no le impide terminar esas actividades, por favor responda sólo la pregunta 8B.

Si usted tiene dolor al realizar deportes que exigen al tendón de Aquiles, y éste le impide terminar esas actividades, por favor responda sólo la pregunta 8C.

8A. Si usted no tiene dolor al realizar deportes que exigen al tendón de Aquiles, ¿Por cuánto tiempo puede entrenar o practicar?

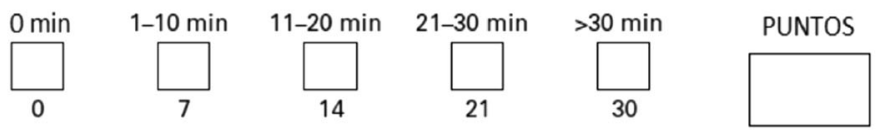

O

8B. Si usted tiene algo de dolor al realizar deportes que exigen al tendón de Aquiles, pero éste no le impide terminar esas actividades, ¿Por cuánto tiempo puede entrenar o practicar?

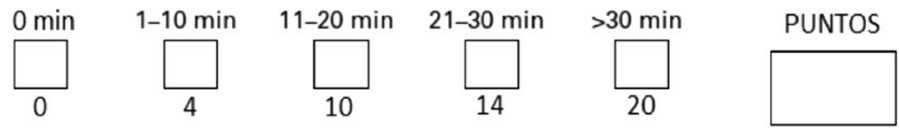

0

8C. ¿Si usted tiene dolor al realizar deportes que exigen al tendón de Aquiles, y éste le impide terminar esas actividades, por cuánto tiempo puede entrenar o practicar?

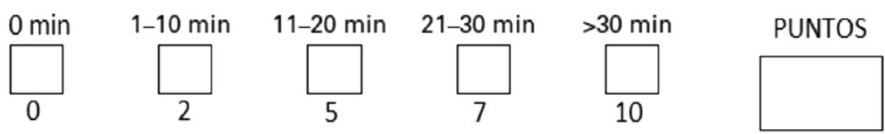

Fig. 5 Image of the final version of the VISA-A-CH questionnaire

Regarding the limitations of the study, the number of participants in the different stages was established according to previous studies of cultural adaptation to other languages, without calculation of sample size. On the other hand, it should be noted that the patients and controls included in both the translation and validation stages are of the same socioeconomic level, not including patients with other education/cultural levels.

\section{Conclusions}

In conclusion, the VISA-A questionnaire was successfully translated and culturally adapted to a Chilean Spanish-speaking populace, carefully following the published guidelines for this process. The ability to measure aspects such as pain and functionality in physical activity highlight the utility of VISA-A-CH for patients with AT. This type of studies is fundamental for subsequent clinical work without methodological errors that occur when patients are evaluated with questionnaires that have not been properly translated and culturally adapted.

\section{Additional file}

Additional file 1: VISA-A-CH. (DOCX $227 \mathrm{~kb})$

\section{Funding}

The authors received no financial support for the research, authorship, and/ or publication of this article.

Availability of data and materials

The datasets used and/or analyzed during the current study are available from the corresponding author on reasonable request. 


\section{Authors' contributions}

AK helped with the study design, organization, translation and adaptation, data analysis, and review. PW helped with the manuscript redaction, data analysis, edition, review, and submission. Gl performed the translation organization, validation, and patient interaction. JC performed the translation organization, validation, and patient interaction. NC and Gl performed the translation organization, validation, and patient interactions. EW, senior author responsible for team planning, performed the analysis and manuscript edition and final approval. NF, senior author, cooperated with the idea, research planning, manuscript edition, and approval. All authors read and approved the final manuscript.

\section{Ethics approval and consent to participate}

We obtained our local IRB approval (Ethical Committee: Comité de Ética de la Investigación, Facultad de Medicina, Clínica Alemana - Universidad del Desarrollo), and every patient gave their consent to participate in this study. All procedures performed in this study were in accordance with the ethical standards of the institutional and/or national research committee and with the 1964 Helsinki declaration and its later amendments or comparable ethical standards.

\section{Consent for publication}

Not applicable

\section{Competing interests}

The authors declare that they have no competing interests.

\section{Publisher's Note}

Springer Nature remains neutral with regard to jurisdictional claims in published maps and institutional affiliations.

\section{Author details}

'Department of Orthopedics, Universidad del desarrollo - Clinica Alemana de Santiago, Vitacura 5951, 7650568 Santiago, Chile. ${ }^{2}$ Universidad de los Andes Hospital Militar de Santiago, Santiago, Chile. ${ }^{3}$ Centre for Sports and Exercise Medicine, Barts and The London School of Medicine and Dentistry, Mile End Hospital, London, UK.

Received: 30 March 2018 Accepted: 5 July 2018

Published online: 13 July 2018

\section{References}

1. Schepsis AA, Jones $\mathrm{H}$, Haas AL. Achilles tendon disorders in athletes. Am J Sports Med. 2002:30:287-305

2. Maffulli N, Khan KM, Puddu G. Overuse tendon conditions: time to change a confusing terminology. Arthroscopy. 1998;14:840-3.

3. Lohrer H. Rare causes and differential diagnoses of Achilles tendinitis. Sportverletz Sportschaden. 1991:5:182-5.

4. Kvist M. Achilles tendon injuries in athletes. Sports Med. 1994;18(3):173-201.

5. Stanish WD, Curwin S, Mandell S. Tendinitis: its etiology and treatment. New York: Oxford University Press; 2000.

6. Myerson MS, McGarvey W. Disorders of the insertion of the Achilles tendon and Achilles tendinitis. J Bone Joint Surg Am. 1998;80-A:1814-24.

7. Maffulli N, Sharma P, Luscombe KL. Achilles tendinopathy: aetiology and management. J R Soc Med. 2004:97(10):472-6.

8. Paavola M, Kannus $P$, Jarvinen TA, Khan K, Jozsa $L$, Jarvinen M. Achilles tendinopathy. J Bone Joint Surg Am. 2002:84-A(11):2062-76.

9. Sorosky B, Press J, Plastaras C, Rittenberg J. The practical management of Achilles tendinopathy. Clin J Sport Med. 2004;14(1):40-4.

10. Andres BM, Murrell GA. Treatment of tendinopathy: what works, what does not, and what is on the horizon. Clin Orthop Relat Res. 2008:466:1539-54.

11. Jonsson P, Alfredson $H$, Sunding K, Fahlstrom M, Cook J. New regimen for eccentric calf-muscle training in patients with chronic insertional Achilles tendinopathy: results of a pilot study. Br J Sports Med. 2008;42(9):746-9.

12. Roos EM, Engstrom M, Lagerquist A, Soderberg B. Clinical improvement after 6 weeks of eccentric exercise in patients with mid-portion Achilles tendinopathy - a randomized trial with 1-year follow-up. Scand J Med Sci Sports. 2004;14(5):286-95.

13. Robinson JM, Cook JL, Purdam C, Visentini PJ, Ross J, Maffulli N, Taunton JE, Khan KM. The VISA-A questionnaire: a valid and reliable index of the clinical severity of Achilles tendinopathy. Br J Sports Med. 2001;35:335-41.
14. Silbernagel KG, Thomee R, Karlsson J. Cross-cultural adaptation of the VISAA questionnaire, an index of clinical severity for patients with Achilles tendinopathy, with reliability, validity and structure evaluations. BMC Musculoskelet Disord. 2005:6:12.

15. Jonge $\mathrm{S}$, de Vos RJ, van Schie HT, Verhaar JA, Weir A, Tol JL. One year follow-up of a randomised controlled trial on added splinting to eccentric exercises in chronic midportion Achilles tendinopathy. Br J Sports Med Jul. 2010;44(9):673-7.

16. Maffulli N, Longo UG, Testa V, Oliva F, Capasso G, Denaro V. Italiant translation of the VISA-A score for tendinopathy of the main body of the Achilles tendon. Disabil Rehabil. 2008:30:1635-9.

17. Silbernagel KG, Thomee R, Eriksson Bl, Karlsson J. Continued sports activity, using a pain-monitoring model, during rehabilitation in patients with Achilles tendinopathy: a randomized controlled study. Am J Sports Med. 2007:35:897-906.

18. Beaton DE, Bombardier C, Guillemin F, Ferraz MB. Guidelines for the process of cross-cultural adaptation of self-report measures. Spine. 2000;25(24):3186-91.

19. Lohrer H, Nauck T. Cross-cultural adaptation and validation of the VISA-A questionnaire for German-speaking Achilles tendinopathy patients. BMC Musculoskelet Disord. 2009;10:134. Erratum in: BMC Musculoskelet Disord 2010;11:37

20. Guillemin F, Bombardier C, Beaton D. Cross-cultural adaptation of health related quality of life measures: literature review and proposed guidelines. J Clin Epidemiol. 1993;46:1417-32.

21. Herdman M, Fox-Rushby J, Badia X. A model of equivalence in the cultural adaptation of HROoL instruments: the universalist approach. Qual Life Res. 1998;7:323-35.

22. Gonzalez-Calvo J, Gonzalez VM, Lorig K. Cultural diversity issues in the development of valid and reliable measures of health status. Arthritis Care Res. 1997:10:448-56

\section{Ready to submit your research? Choose BMC and benefit from:}

- fast, convenient online submission

- thorough peer review by experienced researchers in your field

- rapid publication on acceptance

- support for research data, including large and complex data types

- gold Open Access which fosters wider collaboration and increased citations

- maximum visibility for your research: over $100 \mathrm{M}$ website views per year

At BMC, research is always in progress.

Learn more biomedcentral.com/submissions 